\title{
Customary Law Harmonization Norma Interaction and Legal State in the Management of Natural Resources Conservation
}

\author{
Sigit Sapto Nugroho ${ }^{1}$, Absori $^{2}$, Harun $^{3}$, Rahmanta Setiahadi ${ }^{4}$ \\ Studen of the Doctor Degree Program in Law Science, Muhammadiyah Surakarta University, \\ Lecture Faculty of Law, Merdeka Madiun University ${ }^{1}$ \\ Profesor in Law Science, Faculty of Law, Muhammadiyah Surakarta University ${ }^{2}$ \\ Profesor in Law Science, Faculty of Law, Muhammadiyah Surakarta University ${ }^{3}$ \\ Lecture Faculty of Agriculture, Merdeka Madiun University ${ }^{4}$ \\ \{ sigit.nugroho26@gmail. com $^{1}$ \}
}

\begin{abstract}
Management of natural resource conservation with traditional norms instrument approach on the fact the indigenous peoples of Indonesia more able to preserve environmental functions. Although using the wrong path, for example using the symbol "Ranger sacred," but in essence is successful conservation, so it can keep the reality of natural resources can be preserved sustainability. Compared using legislation by the state, with a rational-steady approach in the conservation of natural resources, in fact, many failures in implementation. For that, we need the debate in determining natural resource management policies between customary norms by state law in the form of legislation.
\end{abstract}

Keywords: Harmonization, Customary Law, State Law, and Natural Resources Conservation

\section{Introduction}

Law normatively natural resource management in Indonesia specified in Article 33 paragraph (3) Of the 1945 Constitution of the Republic of Indonesia. The provisions of Article contains a juridical construction that natural resources in the region of Indonesia is the nation's sovereignty Indonesia. Furthermore management natural resources handed over to the state for the greatest prosperity of the people. In case it can be said that the State can act as a public institution or a private entity.

From this normative side could be called a legal construction that is built based on Article 33 paragraph (3) of the 1945 Constitution, it is clear that in the implementation management including conservation of natural resources can not be separated from the interests of the national economy and the harmony with environmental protection. Therefore, it is undeniable that there should be harmony between natural resource management and environmental protection (conservation) to cater for the greatest prosperity of the people.

Environment conservation through conservation is currently experiencing a variety of problems and obstacles in it. Human needs are not comparable to the natural resources available, which entail a different approach, both to the function of the environment, including the man himself. The contradiction between the needs of humans with natural ability, not only 
have an impact at this time, but will have an impact on the future for the human future. For the development of participatory and community-based conservation is indispensable in maintaining environmental sustainability[1].

At the level of execution (implementation) of various problems in the management of natural resources including natural resource conservation issues not only be solved by putting the law of the State (law) as the only guidelines to solve the problem. Because of the fact juridical found problems include: (1) found in the implementation of legal rules that overlap relating to the management of natural resources in the region with the rules nationally, resulting in discrepancies in the rules so that for the sake of certain interests can damage the environment and harm areas of conservation. (2) the use of multi-interpretation rules are oriented to the interests of exploitation without regard to questions of justice for community. (3) unconsciousness State organs is arrogant to understand the law so that the position of State organs which occur consciously or feel superior to the local community. (4) the existence of indigenous rights and indigenous peoples who often go unnoticed, where the recognition of their existence with certain requirements of Article 3 of the UUPA and Article 18 paragraph (2) 1945 is a reflection of legal politics of hegemony and homogenization. (5) In general there is almost every area there is a tendency in a deductive approach or otherwise it is very weak in the settlement of natural resource use conflicts between the state and the people, resulting in the problem-solving approach is too formal, very black and white and do not produce substantial justice [2].

In other words, the failure of the management of natural resources (conservation) in Indonesia with various models or approaches undertaken by the state, is still a lot experiencing problems/failures in implementation. One thing that often happens is the community involvement in the conservation, sometimes minimized, even eliminated altogether. Customary laws or laws of habit born of, and in the community are not given the opportunity to serve as the norm participate in the success of conservation.

State of conservation politics tends to lead to "better know and understand the country, how do I prevent environmental functions can be achieved", in a manner deemed by the state more rational and logical. This justification gives fatal consequences for the function of the environment, especially a region defined by the state as a conservation area. The model used in the determination of a conservation area, it is not rooted in the real situation in society such as cultural, social, political, and economic.

Most of the conservation area in Indonesia damaged, due to overlapping policies that are rooted in the inconsistency of the legislation with each other, for example between conservation regulations with legislation governing authority of the autonomous regions (decentralization), the policy of granting exploitation of resources nature, legislation in the field of forestry, mining, or oil, and so forth.

Indigenous peoples have the wisdom in terms of relations among members of indigenous peoples, as well as with the surrounding nature. Relationship with the environment in which people live and depend on it is seen as harmony with each other. Legal value live in a society that can be used as a legal content is usually in the form of local wisdom of local communities. Local knowledge is knowledge that is found or obtained from the local community through the accumulation of experiences in a series of practices and integrated with an understanding of the surrounding nature and culture. Local knowledge is always dynamic in accordance with the functions established by the relevant local knowledge and with global situation [3]. The function of local knowledge, among others, to the conservation and preservation of natural resources, meaningful social, ethical and moral [4]. Local knowledge on the ecology and conservation prospects [5]. 
The values of indigenous wisdom is then incorporated into the basic concepts (principles), such as how the relationship between humans and the natural surroundings, the relationship between members of indigenous communities in communion, and so forth. The basic concept that has led to the customary legal instrument to preserve the values that wisdom is maintained until today.

Indigenous peoples have traditional laws, one of which is instrumental in the conservation of natural resources to maintain environmental functions remain harmonious and balanced. One of the instruments is meant customary law in which includes various norms which contains rules about the behavior of how these communities run their social interactions with one another, including with the surrounding nature. Internalization of institutionalized behavior and abstracted in the customary laws of indigenous peoples was followed by a traditional regulatory instruments. Environment conservation by indigenous communities use norms instruments that are not from the state (law legislation), but comes from a norm of customary law. Indigenous forest which is still maintained continuity, is one example that is relevant in conservation approach with the model or with customary law approaches/practices of life and rooted in the community.

Departing from what is described above can be formulated problem is: how to realize the law of interaction dialectical thought natural resource management (conservation) between customary norms by state law?

\section{Method}

Based on themes related to the harmonization of the laws of conservation management of natural resources between traditional norms by state law research method comparative law is a process to learn, understand and align concepts is based on a functional approach and problem-solving as a starting point, a comparison that includes background, origins as well as all the similarities and differences in both modern and traditional.So the comparison method used by way of comparing the law or explanations based on comparative law [6].

\section{Result and discussion}

\subsection{Customary Law as The Living Law}

Customary law is a complex of norms rooted in the sense of justice of the people who have always grown to include the rules of human behavior in everyday life in the community, largely unwritten always adhered to and respected by the people because it has legal consequences (sanctions). Based on the conclusions of the understanding at the same definitions of Customary Law of the above, we can see there is a unity of views on what exactly the Customary Law. Customary law is the law of life in the Society or The Living Law [7].

It is a reaction rather than view in the science of law which was legality (which prioritizes the rule of law contained in the legislation). Where always ignore the growing symptoms of law in society. The use of the term The Living Law is typically used to indicate a wide range of legal grow and develop themselves in society.

Customary Law as the living is a pattern of social life where the legal process, and at the same time is the result rather than the process of civic is the source and basis than the law. The emergence of this law is directly from its fundamental base, namely: Awareness of community 
law in this case are the people of Indonesia. Customary law is a law of life as she explained the real feelings of the people's law. Customary law continues to grow from a real necessities of life, way of life and outlook on life, which overall is a culture of the communities where customary law applies.

Customary Law as the law of Indonesia has its own distinctive style that is different from law system practiced in western countries. Although traditional customary law which means it is tied to a long tradition tradis legacy of their ancestors, but we should not draw hasty conclusions that the Customary Law abstinence changed.

Customary law was in addition to the traditional nature also has shades of "Can change/Dynamic" and have "The ability to adjust/Plastic". Plastic law is when the implementation can be considered separate things. While changes can be made by deleting and replacing it with another regulation abruptly or change is happening because of the influence of the incident, livelihood turns. While the ability to adjust because of the shape of Customary Law was not written and is not codified, then with wide elastic properties at any time to adjust to new circumstances. Customary law is growing and is rooted in the realities of life in the community, because the process occurs and the formation and obeyed (norm process) does not depend on the public authorities.

Customary law community unit is autonomous in regulating the system of life, whether legal, political, economic, and so forth, born and grow together, and maintained by the community it self [8]. Van Vollenhoven said that the definition of indigenous peoples is avolksgemeen-scappen have their own social system, has a strong relationship with the land, natural resources management, as well as having the flexibility to maintain local values or their local wisdom.

While the existence of indigenous peoples to their customary law is aimed at maintaining stability in society, and avoid the occurrence of changes, through the attachment members of the alliance of indigenous, as proposed by Ter Haar, as follows [9]:

- The establishment of the alliance accepted as a natural necessity and a reality metayuridisis

- Therean arrangement arising from the alliance and that puts a person or a group on a notch above the others.

- There are objects, soil, water, plants, temples, buildings, should they retain, maintain, and purify together to maintain the relationship with the forces that do not seem to be getting the reward for them and which do not can be enjoyed by people outside the alliance.

- was no thought on everyone about the possibility to dissolve their alliance.

Legal developments in Indonesian society is a reality of the development of society in Indonesia, the facts contained in Indonesian society, namely: (1) Adaptation of the agrarian; (2) the reliance on a large nature, mainly due to the level of engine technology in underdeveloped and; (3) Agriculture subsistence.

The facts mentioned above, causing held the following values: (1) attachment to fellow members of the community were great, (2) Respect for nature and belief in the existence of forces that are not visible, and (3) Adherence to the leader as requirement for the continuation of community life. The realities of community development in Indonesia that spawned held values, and then gave birth to the norms known as customary law, as the name set for the various rules that can differ from one environment to another environment.

The existence of indigenous and tribal peoples can thus be seen from the various indicators of its existence, as stated by Maria SW Soemardjono, as quoted [8]:

- Having or meet certain characteristics as the subject of customary rights; 
- Their land / territory with certain boundaries as lebensraum (living space) that is the object of customary rights and;

- Powers to perform actions relating to land, other natural resources, as well as legal acts.

\subsection{Law of Conservation of Natural Resources}

Conservation of natural resources that may be commonly known is the conservation of resources in forestry and conservation of natural resources and ecosystems. Whereas the conservation of natural resources it is only a small part of natural resource conservation activities really are.

If we look at the rules of law relating to natural resources in Indonesia, setting the conservation of natural resources can be found in several laws, among others: Act Number 5 of year 1990 on Conservation of Natural Resources and Ecosystems; Act Number 41 of year 1999 on Forestry; Act Number 27 of year 2004 on Geothermal; Act Number 18 of year 2004 on Plantations; Act Number 26 of year 2007 on Spatial Planning; Act Number. 27 of year 2007 on the Management of Coastal Areas and Small Islands; Act Number 30 of year 2007 on Energy; Act Number 4 of year 2009 on Mineral and Coal; Act Number 32 of year 2009 on the Protection and Environmental Management; Act Number 45 of year 2009 on Fisheries.

Clearly, conservation issues can be referenced from Act Number 32 of year 2009 on the Management and Protection of the Environment. Article 1 number 18 is given the meaning of "Conservation of natural resources is a natural resource management to ensure use was wise and continued availability maintain da improve the quality and diversity." Then, in Article 57 paragraph (1) mentioned forms of conservation include: Protection natural resources, preservation of natural resources, sustainable use. While the explanation of Article 57 paragraph (1) letter a confirmed: "Conservation of natural resources include, among others: the conservation of water resources, ecosystems, coastal and marine ecosystems, energy, peatland ecosystems and ecosystem karst."

When looking at the notion of conservation is the preservation and protection precisely these terms can be found in Article 1 paragraph 21 of Act Number 26 year 2007 on Spatial Planning, which states that: the protected area is an area defined by the main function of protecting the environmental sustainability that include natural resources and resource artificial. Following a referral is emphasized in the rules implementation stipulated in Presidential Decree Number 32 of year 1990 on protected Areas, which provide the same sense of Article $3 \mathrm{~s} / \mathrm{d}$ Article 6 is known of the protected areas, among others:

- Areas that provide protection of the area below it consists of : area of protected forests, peaty, area water infiltration.

- Protected area local (consisting of coastal border, the border suangan, the area around the reservoir, the area around the springs.

- Reserves of natural and cultural heritage (consisting of nature reserves, nature reserves ocean and other waters: coastal areas forested mangrove, garden national, forest parks, and natural park, the area of cultural heritage and science.

- Areas prone to natural disasters (not the detail anything just creteria that region identified often and high potential of natural disasters such as volcanic eruptions, earthquakes, and landslides).

- Poor regions is called a conservation area, so not only forests, mountains or national parks, and nature reserves as people know.

Act Number 5 of year 1990 on Conservation of natural Resources and Ecosystems, which is a positive norm on the conservation of natural resources loading, that: "the system 
protection settings buffer life, preservation of diversity of plants and animals and their ecosystems sustainable use of natural resources and ecosystems in order to ensure their use for the welfare of society and improving the quality of human life. But conservation in Indonesia is influenced by a worldview which was adapted from the ideology of nature conservation classical (classic nature consevation), meaning that every person prohibited from entering and indulge in an area that has been designated as a conservation area. This ideology is in line with the perspective that considers ecofascism environmental factors are more important than people's lives [10].

Perspective with regard to environmental issues as a critical reflection Dietz that the environmental movement or those who work for environmental issues is simply divided into several groups of flow. The first is the environmental movement grouped as environmental facism (eco-facism). The neighborhood is those fighting for environmental issues for the sake of the environment itself. With all the risks in any environment need to be protected. According to Dietzideology second is the environmental movement: those who fight for the preservation of the environment is not for the sake of the environment itself, but especially for the continuation of economic growth and capital accumulation (capitalism). This group may be called as a development environment (eco-developmentalism). Environment should be preserved because it ensures constancy of industrial raw materials so that the economic growth (read $=$ capital formation) is on going. The motto "sustainable development (sustainable development) was introduced to legitimize the growth and development of the capitalists. So actually conserved is the development and growth of the capitalist economy itself. Environmental reasons only one of its appliances [11]. So that tends to their commercialization including conservation forest region [12].

Unlike the above two groups is the emergence of the so-called populist environment (ecopopulism). This group is activist environmental movement that is very partial to the ordinary people, the environment for the welfare of the people. The famous motto "Forests for people". The environmental group was thinking critically populist who has rights to the environment or natural resources within the area there? Who benefits from natural conservation? Such questions have become an urgent agenda for them. In contrast to the fascist group environment where for the sake of the environment or natural resources itself if necessary displacing local people of an area. The environment must be purified including indigenous people who live and grow in the region. Community-based natural resource management plays an important role [13].

\subsection{Norm Dialectical Interaction Indigenous and State Law in the Management of Natural Resources Conservation}

Law basically has his own world, but the interaction between the law society or informal institutions that will always overshadow the workings of law in society. According to Paul Bohannan as quoted [14] see, that there is interaction with it, as he said, that the habits that should grow to eventually be in accordance with the law, or he must actively resist it. Laws should grow to eventually accordance with custom, or he must deny or suppress it.

Based on the contents customary law and regulations require the public good, providing rules for the deeds of human birth [15]. See that law and custom have a partnership, namely:

- Law and customary addressed to man as a creature of social, not merely individual alone.

- Laws and customs satisfied with the behavior of birth, and not asking goodwill that support the behavior. 
- Law and customary nature heteronomic placed upon us by public.

- law and custom to give rights demands something behavior in accordance with its rules.

Satjipto Raharjo said that the customs (customary law) can not be entirely abandoned, although some countries have already adopted the legal system legislation their communities addition to the country. Community law organized by legal laws and regulations, while others by social norms that included habit. Customary law is the ideals of the legal and moral ideals are noble which includes the atmosphere kejiawaan as well as the character of the Indonesian nation is solidified in Pancasila and the Constitution of 1945 is one of the resources essential to obtain materials for the development of national laws leading to the legal unification [16].

Supomo mind on an important position is to lift the customary law of indigenous local communities into national law. Supomo argues that although not in the form of rules, may be realized in the form of principles elaborated further into modern legal principles. This view is basically opposite of Von Savigny historical understanding, that the law could not be made and imposed from above (as or not as a means of social engineer), but will have to grow flowers and coincided with the growth of the community itself [16].

Natural resource management at the level of implementation in general is centralized. Various provisions of Act Number 5 of year 1990 on Conservation of Natural Resources and Ecosystems shows that the authority of the (central) government or the Minister is very dominant, although as the provisions of Article 4 of this law states that the conservation of natural resources and ecosystems is a responsibility responsibilities and obligations of government and society. Article 8, paragraph (1) states that to achieve the conservation objectives referred to above, the government (central) establish: (a) the specific area as the area of protection of life support systems; (b) the basic pattern formation region protection of life support systems; (c) setting means the utilization of protected areas of life support systems Article 9, paragraph (2) also provides the authority to organize and conduct disciplinary action against the use and management of land and exploitation rights in the waters located within the protection of life support systems.

Along with a centralized approach to the law on the conservation of natural resources, this does not deal with the recognition of legal pluralism in the conservation of natural resources. Including gender equality, recognition of indigenous and tribal peoples (MHA) is also not regulated. Article 37 of this law despite the offensive role of the community in the conservation of natural resources and ecosystems. Government should lead and mobilize the people's role in conservation through the efficient and effective manner. Besides, the government also must cultivate and increase awareness in conservation of natural resources and ecosystems through education and counseling. Therefore MHA is a part of the people of Indonesia, the efforts to increase the participation of people dala these activities implicitly also the role of the MHA [17].

Factors that unconscious state organs when approached with the community to achieve its goals exploit natural resources in a region is looking at the community as a party to subordinate so that it can be easily approached/ affected. Often not unthinkable that the environment around them, people have historically filled the inner attachment value. As a result, the public will not easily surrender their rights on a particular property. Further impact of government programs in order to create prosperity for the people can be constrained only wrong in its approach to the community.

The existence of MHA in fact still not acknowledged its existence in spite of the juridical recognition of their existence is expressly specified in the Constitution and various legislations. The absence of adequate recognition of the role of government in the task mislead 
management natural resources (conservation) as if the most important roles (single actor). However, the incidence of the reverse also occurs: lifestyle factors and poverty also encourage people to impose its will in order sustain life. As a result, natural resource environment (conservation) are managed careless, destructive and irresponsible. As stated by Garret Hardin was quoted [18] as the "Tragedy of the Common [19]"

Fact tragedy of the common can be avoided through mechanisms that can lead to an individual perceives the goods or common property resources as well as the institutions that govern them. The transfer of property rights (tenure) sometimes interrupt the continuous availability of resources, due canging people's behavior on the resources where the resources that were previously protected well into the resources exploited. The transformation process mastery of the resources of a managed resource indigenous peoples into these resources belong to the State in many countries has led to: (1) local instutional wisdom removal, (2) the occurrence of a situation in which the capacity for monitoring and control of state institutions became weak especially natural resources large-scale claimed as the power of the State; (3) utilization of resources trapped in conditions of de facto open access ${ }^{l}$ and tend to the parties would be competing to utilize maximum resources for the benefit of each.

Sourced from the reality of the phenomena related to natural resource management (including conservation) resulting in environmental damage derived from: (1) poverty, (2) weak law enforcement; (3) the low level of synchronization related regulations sumer management of natural resources; (4) encouragement increased local revenues; (5) protection (conservation) and the management of natural resources is not the main priority; (6) has not been strong recognition of local knowledge; (7) attempt to impose the will through legal instruments. Under these conditions, the politics of law in the management of natural resources (including the conservation of natural resources) must be able to reflect the character of: pro-order, pro-social justice, pro-welfare, pro-poor, pro-indigenous, pro-environment [2]

Thus already should policy makers in the management of natural resources (including conservation) a good understanding of the plurality of law local communities thus soon to articulate between State law and customary norms (local law) and harmonize between national interests and the local communities, so that the process of renewal that is accepted by society as a product of the interaction of local legal/customary norms with State law. Development of national law must constitute the Dialogic product vertically between local law/ customary norms with the laws of the State and at the same horizontal dialogic between local laws/traditional norms.

Management of natural resources (conservation) with the approach using instruments customary norms in fact in many indigenous peoples of Indonesia more able to maintain the conservation of environmental functions. Although using irrational approach, for example using the symbol "Ranger sacred", but in essence is a successful conservation is done, so that we can witness natural resources can still be maintained continuity. Compared with the means of legislation by the state, with a rational-steady approach in the conservation of natural resources, in fact many failures in implementation. ${ }^{2}$

\section{Conclusion}

The failure of natural resource management (conservation) in Indonesia with various models or approaches undertaken by the state, is still a lot experiencing problems/failures in 
implementation. One thing that often happens is, even abolished altogether customary norms / local law or the laws of habit born of, and in the community are not given the opportunity to serve as the norm participate in the success of conservation. The State as holder of power in the management of natural resources (conservation) tend countries consider themselves the most knowledgeable and most understand that as if the issue of conservation of natural resources can only be solved by putting the law of the State (law) as the only guideline for resolving problems the. Departing from such failures should policy makers in the management of natural resources (including conservation) a good understanding of the plurality of law local communities thus soon to articulate between State law and customary norms (local law) and harmonize between national interests and the local communities, so that the process of renewal received by the public as a product of the interaction of local legal/customary norms of the laws of synergy in realizing the protection of natural resources in a sustainable manner.

\section{References}

[1] C. Lisa and V. M. Arja, "Participatory Development and Comumunity-Based Conservation: Opportunities Missed for Lesson Learned," Hum. Ecol. J., vol. 31, no. 3, pp. 417-437, 2017.

[2] S. Aji, Membangun Politik Hukum Sumber Daya Alam Berbasis Cita Hukum Indonesia. Yogyakarta: Tafa Media, 2015.

[3] S. Ade, Budaya Hukum dan Kearifan Lokal. Jakarta: UP Pres, 2013.

[4] I. Mariane, Kearifan Lokal Pengelolaan Hutan Adat. Jakarta: Raja Grafindo, 2014.

[5] K. B. Ryan and S. M. M. Lachlan, "Trends and Prospects for Local Knowledge in Ecological an Conservation Research an Monitoring," Biodivers. an Conserv. J., vol. 17, no. 14, pp. 3501-3512, 2008.

[6] M. M. Peter, Penelitian Hukum. Jakarta: Airlangga Press Kencana, 2005.

[7] S. N. Sigit, Pengantar Hukum Adat. Surakarta: Iltizam Indonesia, 2016.

[8] S. Ade, Hukum dan Kearifan Lokal; Revitalisasi Hukum Adat Nusantara. Jakarta: PT Grasindo, 2010.

[9] R. Satjipto, Hukum dan Perubahan Sosial; Suatu Tinjauan Teoritis serta Pengalamanpengalaman di Indonesia. Indonesia: Genta Publishing, 2009.

[10] S. Arianto, "Menuju Pengelolaan Taman Nasional Lore Lindu Berbasis Masyarakat, Kertas Posisi Walhi Sulawesi Tengah, 01/Wallhi/2002." 2002.

[11] T. Dietz, Pengakuan Hak Atas Sumber Daya Alam Kontur Geografi Lingkungan Politik. Yogyakarta: Insist Press, 2005.

[12] J. M. Arnold and M. R. Pérez, "Can Non-timber Forest Product Match Tropical Forest Conservation an Development Objectves," Ecol. Econ., vol. 39, no. 3, pp. 437-447, 2001.

[13] K. Chetan, "Revisiting 'Community' in Community-Based Natural Resources Management," Oxford Journal, Soc. Sci. Community Dev., vol. 40, pp. 275-285, 2005.

[14] R. Satjipto, Hukum dan Masyarakat, Angkasa. Bandung, 1980.

[15] Van Apeldoorn, Pengantar Ilmu Hukum. Jakarta: PT. Pradnya Paramita, 2000.

[16] W. Soetandyo, Dari Hukum Kolonial Ke Hukum Nasional; Dinamika Sosial-Politik dalam Perkembangan Hukum di Indonesia. Jakarta: Huma, 2015.

[17] T. Nasarudin, "Hukum Atas Hak Asasi Masyarakat Adat Dalam Pengelolaan Sumber Daya Hutan Di Provinsi Maluku," J. Sasi, vol. 16, no. 4, p. 2010, 2010.

[18] M. S. Sumardjono, N. Ismail, E. Rustiadi, and A. A. Damai, "Pengaturan Sumber Daya Alam Di Indonesia Antara Yang Tersurat dan,” 2011. 
[19] S. F. McWhinnie, "The tragedy of the commons in international fisheries: An empirical examination," J. Environ. Econ. Manage., vol. 57, no. 3, pp. 321-333, 2009. 